\title{
Studies on Structure of Cuprammonium Cellulose II. Structural Change of Cellulose-Cuprammonium Complex as a Function of Hydroxyl Ion Concentration
}

\author{
Ikuya Miyamoto, Yoshio Matsuoka, Toshihiko Matsui, \\ and Kunihiko OKaJIMA \\ Fundamental Research Laboratory of Natural and Synthetic Polymers, \\ Asahi Chemical Industry Co., Ltd., 11-7 Hacchownawate, \\ Takatsuki. Osaka 569, Japan
}

(Received June 16, 1995)

\begin{abstract}
As an extension of our previous study on cellulose-cuprammonium system, ${ }^{1}$ an attempt was made to clarify the structure of cellulose-cuprammonium complex in the solid-liquid coexisting system by applying the fact that dissolution of cellulose into cuprammonium solution depends strongly on $\mathrm{OH}^{-}$concentration in the system. Electro-conductivity measurements on aqueous (aq) cuprammonium complex revealed that the complex existed as dissociated type at $C_{\mathrm{OH}}\left(\mathrm{OH}\right.$ concentration for aq solution) $<0.3 \mathrm{moll}^{-1}$ and as undissociated type at $C_{\mathrm{OH}}>0.5$. Absorption reaction of aq cuprammonium complex on solid cellulose was also dependent on $C_{\mathrm{OH}}$, revealing that the reaction order of $\mathrm{OH}^{-}$ion for the solid-liquid absorption reaction is unity and 0 for the system with $C_{\mathrm{OH}}$ less than $0.3 \mathrm{moll}^{-1}$ and for the system with $C_{\mathrm{OH}}>0.5 \mathrm{moll}^{-1}$, respectively. Meanwhile, the reaction order of copper to cellulose was found unity regardless the $C_{\mathrm{OH}}$ value. The latter fact might deny the random reaction of $3 \mathrm{OH}$ groups in glucopyranose unit with copper ion and suggests indirectly the regio-selective complex formation of cuprammine and $\mathrm{OH}$ groups at $\mathrm{C}_{2}$ and $\mathrm{C}_{3}$ as previously proved. It was found that even if the molar ratio of copper ion in aq cuprammine complex to solid cellulose is more than unity, copper absorbed on solid cellulose is at most $0.65 \mathrm{~mol} \mathrm{~mol}^{-1}$. This value is quite near to that evaluated for the cellulose dissolved in cuprammonium solution. Using the above results a tentative new cellulose dissolving process is proposed, in which the less amount of copper and $\mathrm{NH}_{3}$ are employed, compared with those used for conventional process.

KEY WORDS Cuprammonium Cellulose / Hydroxyl Ion / Electroconductivity / Glucopyranose / Cupric Ion / Absorption Reaction /
\end{abstract}

In the previous study ${ }^{1}$ we carried out analysis on cellulose and regio-selective cellulose derivative dissolved in cuprammonium solution by ultraviolet (UV) and circular dichroism (CD) spectrometries, revealing that 1) copper selectively coordinates to hydroxyl groups at $\mathrm{C}_{2}$ and $\mathrm{C}_{3}$ positions of glucopyranose units in cellulose giving a cellulose-cuprammonium complex with charge transfer (CT) excitation around $300 \mathrm{~nm}, 2$ ) the CT excitation relates to negative Cotton effect for cellulose with degree of polymerization $(D P)$ more than 3,3$)$ the origin of the Cotton effect might be related to $\delta$ chelate conformation of cellulose-cupram- monium complex, and 4) intensity of CT absorption levels off when molar ratio of copper to glucopyranose unit of cellulose $(\mathrm{Cu} / \mathrm{Cell})$ in the solution exceeds $0.6-0.7$, predicting the existence of some chemical equiriblium state (and saturated states) between cellulose, cuprammonium complex and cellulose-cuprammonium complex in the solution. The above results mostly support the idea proposed by Reeves ${ }^{2}$ that cellulose-cuprammonium complex is a salt of cuprammonium complex cation and diol anion at $\mathrm{C}_{2}$ and $\mathrm{C}_{3}$ positions on glucopyranose ring but differs from his prediction that $\mathrm{Cu} / \mathrm{Cell}$ ratio is unity 
for the above cellulose-cuprammonium complex. Concerning the reaction equiriblium study between cellulose, cuprammonium complex, and cellulose-cuprammonium complex in the above solution was first reported by Hess and his coworkers ${ }^{3}$ by measuring optical rotation of the cellulose-cuprammonium solution assuming that the optical rotation of the system is result of the formation of the cellulose-cuprammonium complex. They found that the following relationship held as a result of the equilibrium of the complex-forming reaction between one mol of cellulose and one mol of cuprammonium complex.

$$
\frac{[\text { Cellulose-Cuprammonium complex }]}{[\text { Cellulose }] \times[\text { Cuprammonium complex }]}=K
$$$$
\text { ( } K \text {, constant; [ ], concentration) }
$$

However, they neglected the effect of sodium hydroxide $(\mathrm{NaOH})$ on the above equilibrium despite of their findings that an addition of small amount of $\mathrm{NaOH}$ into a cellulose-cuprammonium solution system resulted in an increase of optical rotation of the system. Further, it has been known that $\mathrm{NaOH}$ concentration in cuprammonium solutions influenced their dissolving power giving maximum dissolving ability at $100 \mathrm{mmoll}^{-1}$ and losing dissolving power at more than 200 mmoll $1^{-1}$ for purified ramie under the initially charged cellulose concentration of $0.8 \%{ }^{4}$ Sobue $^{5}$ also described that solubility of cellulose was very low in a cuprammonium solution containing $770 \mathrm{mmoll}^{-1}$ of $\mathrm{NaOH}$. Considering these facts we can choose the experimental conditions under which cellulose does not dissolve in cuprammonium solution but apparently absorbs $\mathrm{Cu}$. In this solid-liquid coexisting system, separation of $\mathrm{Cu}$-absorbing cellulose from the solution becomes much easier without severe morphological change, hence compositional change, compared with those recovered from the cellulose dissolved in cuprammonium solution. $^{6-9}$ As mentioned before, our previous study ${ }^{1}$ showed that com- plex-forming copper is at most $0.6-0.7 \mathrm{~mol}$ per glucoside residue and the excess amount of cuprammonium complex coexists with cellulose-cuprammonium complex. And if the complex-forming equilibrium between cellulose and cuprammonium complex also exists in this solid-liquid coexisting system similarly as the equilibrium in the solution the $\mathrm{Cu}$-absorbing cellulose might also take some specified complex structure. Therefore, it is very interesting to compare the structure of cellulose-cuprammonium complex in the solution with that for solid state $\mathrm{Cu}$-absorbing cellulose for the much more detail understandings of dissolved state of cellulose in cuprammonium solution. For the purpose, an attempt was made to analyze a kind of absorption equilibrium as a function of $\mathrm{NaOH}$ or $\mathrm{OH}^{-}$ion concentration in the cuprammonium solution for elucidation of cellulose-cuprammonium complex structure.

\section{EXPERIMENTAL}

\section{Materials}

A regenerated cellulose sample (the viscosityaverage degree of polymerization $D P_{\mathrm{v}}=364$ ) recovered from its cuprammonium solution was used. A commercially available cuprammonium solution (viscosity-measurement grade) was supplied from Kishida Chemicals Co., Ltd., Japan, and its initial copper $(\mathrm{Cu})$ and ammonia $\left(\mathrm{NH}_{3}\right)$ concentrations $\left(C_{\mathrm{Cu}}\right.$ and $C_{\mathrm{NH}_{3}}$, respectively, expressed by $\mathrm{moll}^{-1}$ ) were adjusted by diluting with deionized water in order to lower its solubility power. And its initial hydroxyl ion $\left(\mathrm{OH}^{-}\right)$concentration $\left(C_{\mathrm{OH}}\right.$ expressed by $\mathrm{moll}^{-1}$ ) was adjusted to give $0.07-2.5 \mathrm{moll}^{-1}$ by adding $4 \mathrm{~N}$ of aqueous (aq) sodium hydroxide. The resulting solutions $\left(\mathrm{Cu} / \mathrm{NH}_{3} /\right.$ sucrose $/ \mathrm{OH}^{-}=0.052 / 2.4 / 0.011 /$ $0.07-2.5, \mathrm{moll}^{-1}$ ) were employed for the treatment of the cellulose sample. $C_{\mathrm{Cu}}$ in the solution was examined by chemical analysis, and $C_{\mathrm{OH}}$ was determined by $\mathrm{pH}$ measurement. $C_{\mathrm{NH}_{3}}$ and sucrose content in the solution were 
calculated by considering dilution factor from those described by supplier.

\section{Sample Treatment and Analytical Procedure}

For better understanding of the analytical procedure, one concrete example is described below and the procedure is schematically shown in Figure 1. About $1.7 \mathrm{~g}$ of the regenerated cellulose with equilibrium water retention was immersed in $142.8 \mathrm{~g}$ of cuprammonium solutions $\left(\mathrm{Cu} / \mathrm{NH}_{3} /\right.$ sucrose $/ \mathrm{OH}^{-}=$ $0.052 / 2.4 / 0.011 / 0.07 \mathrm{moll}^{-1}$ ) stocked in an Erlenmeyer flask with silicon rubber stopper at $25^{\circ} \mathrm{C}$ for $1 \mathrm{~h}$ in a dark place and the undissolved crude blue cellulose solid (hereafter denoted as CBC) was separated from the resulting solution (hereafter denoted as liq. A) by passing through a glass filter (ISO G-4 grade) under vacuum. The CBC was washed with $c a .20 \mathrm{ml}$ of methanol, dried at $50^{\circ} \mathrm{C}$ for $2 \mathrm{~h}$. The resulting washing liquids separated in this stage were mixed with liq. A. The dried blue cellulose sample (hereafter denoted as DBC) was subjected to chemical analyses to determine $\mathrm{Cu}$ content absorbed by the cellulose solid. The liq. A was acidified with $1 N$ hydrochloric acid $(\mathrm{HCl})$ to precipitate the cellulose dissolved in the solution. The precipitates (crude recovered cellulose) in the neutralized media are centrifuged at $10000 \mathrm{rpm}$ for $40 \mathrm{~min}$ by using a centrifugal apparatus (Type CR 20B2, Hitachi
Co., Ltd., Japan), filtered out by a glass filter (ISO G-4 grade), washed by water, followed by drying at $90^{\circ} \mathrm{C}$ for $2 \mathrm{~h}$ and then weighed ( $w_{\mathrm{s}}$ g). The acidified solution was stocked for chemical analysis. DBC samples were subsequently subjected to regeneration process where $\mathrm{DBC}$ was regenerated with $1 N \mathrm{HCl}$ at $25^{\circ} \mathrm{C}$ for $2 \mathrm{~h}$, washed by water, dried in air and finally dried at $90^{\circ} \mathrm{C}$ for $2 \mathrm{~h}$, and weighed $\left(w_{\mathrm{ns}}\right)$. The resultant washing liquids were subjected to $\mathrm{Cu}$ analysis to estimate $\mathrm{Cu}$ content absorbed by the cellulose. The procedure described above were applied for the systems where the amount of cellulose varies from $0.2 \mathrm{~g}$ to $3.00 \mathrm{~g}$ in each $142.8 \mathrm{~g}$ of cuprammonium solutions with different $C_{\mathrm{OH}}\left(=0.07-2.5 \mathrm{moll}^{-1}\right)$ but keeping the concentrations of other components constant.

\section{Analyses}

The viscosity-average degree of polymerization $D P_{\mathrm{v}}$ of the regenerated cellulose used was determined to be 364 from the limiting viscosity number $[\eta]$ in cadoxen at $25^{\circ} \mathrm{C}$ using following equation $^{10}$ :

$$
\begin{gathered}
{[\eta]=3.85 \times 10^{-4} M_{w}^{0.76}} \\
D P_{v}=M_{w} / 162
\end{gathered}
$$

\section{Electro-Conductivity (EC) Measurements}

$\mathrm{EC}$ of cuprammonium solution was mea-

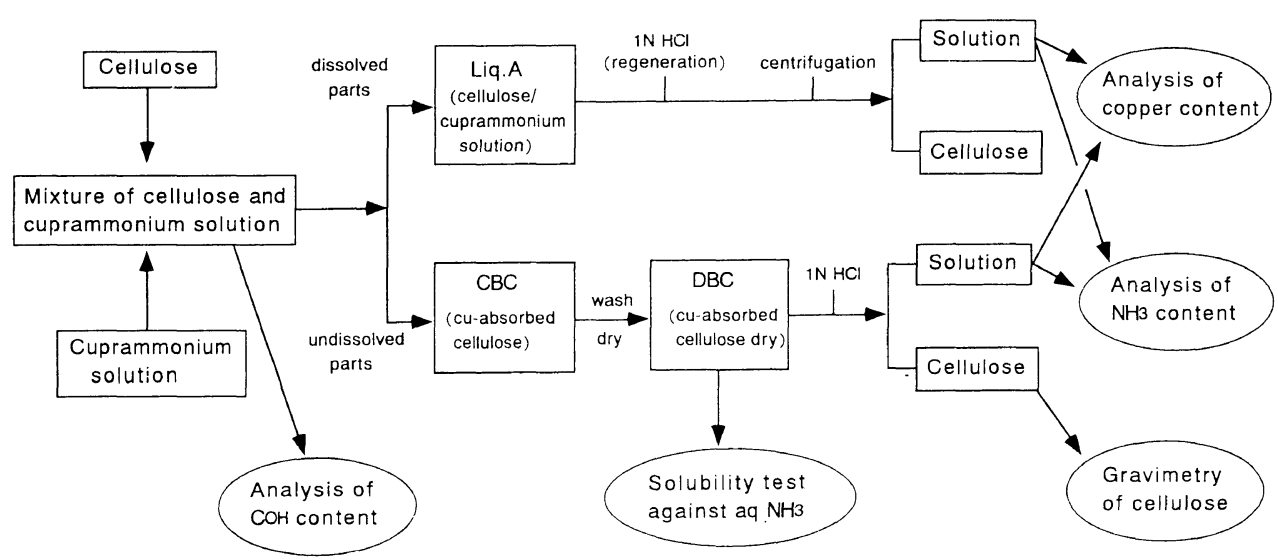

Figure 1. Shematic procedure of sample treatment and analysis. 
sured by a conduct-o-meter (model CM-2A, Toa Denpa Co., Ltd., Japan) with platinumblack conductivity cell (Type CG201PL, cell constant $=0.995 \times 1$ ) at $25.0^{\circ} \mathrm{C}$ by adding $4 N$ of aq $\mathrm{NaOH}$ solution slowly and dropwisely $\left(0.2 \mathrm{ml} \mathrm{min}^{-1}\right)$ with aid of a burette to the original cuprammonium solution $\left(\mathrm{Cu} / \mathrm{NH}_{3}\right)$ sucrose $\left.=0.071 / 3.4 / 0.016, \mathrm{moll}^{-1}\right)$ in order to avoid rapid temperature rise caused by the addition of alkali with stirring, as a function of $\mathrm{NaOH}$ concentration. Care was also taken to avoid vaporization of ammonia from the system. The similar measurement was carried out for the the same cuprammonium solution with $0.55 \mathrm{moll}^{-1}$ cellulose and $3.4 \mathrm{moll}^{-1}$ aq $\mathrm{NH}_{3}$ solution (of which $\mathrm{NH}_{3}$ concentration is the same as that for starting cuprammonium solution), by adding $4 \mathrm{~N} \mathrm{NaOH}$ as reference.

\section{Hydroxyl Ion Concentration of the Cupram- monium Solution}

$\mathrm{pH}$ of cuprammonium solutions with different $C_{\mathrm{OH}}$ was measured by a glass electrode type pH meter (Model HM-18, Toa Denpa Co., Ltd., Japan) at $20^{\circ} \mathrm{C}$. Before measurement the $\mathrm{pH}$ meter was attenuated at $20^{\circ} \mathrm{C}$ to precisely indicate $\mathrm{pH}=13.1$ by using $0.10 \mathrm{~N}$ aq $\mathrm{NaOH}$ standard solution. The measured $\mathrm{pH}$ value was translated to $\mathrm{OH}^{-}$ion concentration using the following equation:

$$
C_{\mathrm{OH}}=10^{(\mathrm{PH}-14)}
$$

Solubility of Cellulose in Cuprammonium Solutions $\left(S_{\mathrm{c}}\right)$

$S_{\mathrm{c}}$ was defined as following equation.

$$
S_{\mathrm{c}}=100 \times w_{\mathrm{s}} /\left(w_{\mathrm{s}}+w_{\mathrm{ns}}\right) \quad(\%)
$$

Here, $w_{\mathrm{s}}$ and $w_{\mathrm{ns}}$ are weights for dissolved and undissolved parts of cellulose.

Initial cellulose concentration $C_{\text {Cell }}$ charged to cuprammonium solution is defined as;

$$
\begin{gathered}
C_{\text {Cell }}=1000 \times\left(w_{\mathrm{s}}+w_{\mathrm{ns}}\right) / 162 / 142.8 / \rho \\
\left(\mathrm{moll}^{-1}\right)
\end{gathered}
$$

Here, $\rho$ is density of cuprammonium solution at $25^{\circ} \mathrm{C}$.

\section{Copper Content}

Copper contents $\left(w_{\mathrm{Cu}}\right)$ were determined gravimetrically by converting cupric ion into cupric sulfide $(\mathrm{CuS})$ in the following manner; $2.0 \mathrm{~g}$ of sodium sulfide 9 hydrates $\left(\mathrm{Na}_{2} \mathrm{~S}\right.$. $9 \mathrm{H}_{2} \mathrm{O}$ ) was added in the cuprammonium solution and stood at room temperature for $8 \mathrm{~h}$ to produce black precipitate of $\mathrm{CuS}$ completely. The $\mathrm{CuS}$ was separated on a glass filter, whose weight $\left(\mathrm{W}_{\mathrm{g}}\right)$ was measured in advance after drying at $105^{\circ} \mathrm{C}$ for $3 \mathrm{~h}$, and the total weight of the $\mathrm{CuS}$ with the glass filter $\left(W_{\mathrm{gc}}\right)$ was measured after drying at $105^{\circ} \mathrm{C}$ for $3 \mathrm{~h}$.

$$
w_{\mathrm{Cu}}=\left(W_{\mathrm{gc}}-W_{\mathrm{g}}\right) \times 63.55 / 95.61
$$

$C_{\mathrm{Cu}}$ (expressed in $\mathrm{moll}^{-1}$ ) of starting cuprammonium solution with precise volume (at $25^{\circ} \mathrm{C}$ ) was also determined in the same manner after acidifying the cuprammonium solution with $1 N \mathrm{HCl}$. Molar absorption of $\mathrm{Cu}$ on the undissolved cellulose at equilibrium $\left(M_{\mathrm{Cu}} /\right.$ $\left.M_{\text {Cell }}\right)$ is defined as;

$$
M_{\mathrm{Cu}} / M_{\mathrm{Cel1}}=\left(w_{\mathrm{Cu}} / 63.55\right) /\left(w_{\mathrm{ns}} / 162\right)
$$

\section{Production of Cellulose-Cuprammonium Solu- tion}

The DBC sample obtained by using the cuprammonium solution of $C_{\mathrm{OH}}=0.60 \mathrm{moll}^{-1}$ was washed by water at $5^{\circ} \mathrm{C}$, methanol and dried at $50^{\circ} \mathrm{C}$ for $2 \mathrm{~h}$ to remove an excess $\mathrm{NaOH}$ absorbed on the sample. $7.5 \mathrm{~g}$ of this washed DBC sample was mixed with $42.5 \mathrm{~g}$ of $2.5 \%$ aq ammonia solution in a flask and immediately strong agitation was done by the mechanical stirrer for $2 \mathrm{~min}$. The DBC sample was completely soluble in this condition and cellulosecuprammonium solution was obtained. The cellulose concentration of this solution calculated by the analytical data of the DBC sample was 9.1, and this value is almost equal to the conventional cellulose-cuprammonium solution using in the cellulose industry. The ratio of copper and cellulose $\left(M_{\mathrm{Cu}} / M_{\text {cell }}, \mathrm{mol} / \mathrm{mol}\right)$ in the solution calculated in a same manner was 0.52 , and this value is almost a half to the conventional cellulose-cuprammonium solu- 
tion. The ammonia concentration of this solution was $2.1 \%$, and this value is almost one third to the conventional cellulose-cuprammonium solution.

\section{RESULTS AND DISCUSSION}

Figure 2 shows electro-conductivity EC of cuprammonium solutions and cuprammonium solution dissolving cellulose as a function of $C_{\mathrm{OH}}$ added in the system. On the horizontal axis the corresponding $\mathrm{NaOH}$ concentration $\left(C_{\mathrm{NaOH}}\right)$ is also shown. Here, a reference line obtained for aq $3.4 \mathrm{moll}^{-1} \mathrm{NH}_{3}$ solution is also shown. EC of aq $\mathrm{NH}_{3}$ seems to have two linear regions against $C_{\mathrm{OH}}$ or $C_{\mathrm{NaOH}}$. In the first linear region $\left(C_{\mathrm{NaOH}}<0.02 \mathrm{moll}^{-1}\right)$ there might exist dissociation form of $\mathrm{NH}_{3}$ (that is, $\mathrm{NH}_{4}^{+}$) and in the second linear $C_{\mathrm{OH}}$ region $\left(C_{\mathrm{NaOH}} \geqq 0.02 \mathrm{moll}^{-1}\right)$ the dissociation of $\mathrm{NH}_{3}$ might be restricted because dissociation constant of $\mathrm{NH}_{3}\left(=10^{-9.24}\right)$ is very low even in water. ${ }^{11} \mathrm{EC}$ of cuprammonium solution deviates significantly to higher side from the two linear lines obtained for aq $\mathrm{NH}_{3}$ in low $C_{\mathrm{NaOH}}$ region and seems to fall on the second linear line for aq $\mathrm{NH}_{3}$ in $C_{\mathrm{NaOH}}$ region more than $c a .0 .24 \mathrm{moll}^{-1}$. This strongly suggests that cuprammonium complex exists in its undissociated state in the region of $C_{\mathrm{NaOH}}>c a$. $0.24 \mathrm{moll}^{-1}$. Therefore, the following example

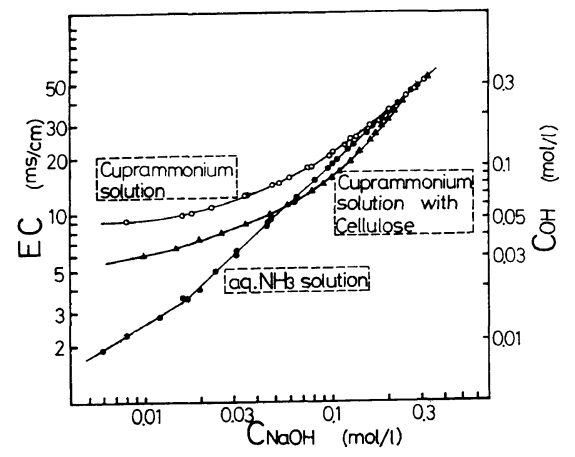

Figure 2. Electro-conductivity (EC) of cuprammonium solution as a function of $\mathrm{NaOH}$ concentration $\left(C_{\mathrm{NaOH}}\right)$ : , aq $\mathrm{NH}_{3}$ system; $\mathrm{O}$, cuprammonium solution system; $\boldsymbol{\Delta}$, cuprammonium solution system with cellulose. of dissociation equilibria of cuprammonium complex might be anticipated depending on $C_{\mathrm{NaOH}}$ in the system:

$$
\begin{aligned}
& \mathrm{Cu}\left(\mathrm{NH}_{3}\right)_{1}(\mathrm{OH})_{2} \leftarrow \rightarrow \mathrm{Cu}^{+}\left(\mathrm{NH}_{3}\right)_{\mathrm{m}} \mathrm{OH}+\mathrm{OH}^{-} \\
& \leftarrow \rightarrow \mathrm{Cu}^{2+}\left(\mathrm{NH}_{3}\right)_{n}+2 \mathrm{OH}^{-} \\
& C_{\mathrm{NaOH}}>0.24 \mathrm{moll}^{-1} \quad C_{\mathrm{NaOH}}<0.24 \mathrm{moll}^{-1}
\end{aligned}
$$

These dissociation equilibria of cuprammonium complex might also exist in the cellulose-cuprammonium coexisting system. But the EC line on the figure was detected as a little lower than the cuprammonium system in the cellulose-soluble composition because of the higher viscosity of the solution.

Since the concentration of $\mathrm{OH}$ or $\mathrm{NaOH}$ in cuprammonium solution has long been pointed out to influence the solubility of cellulose, ${ }^{8,9}$ the solubility $S_{\mathrm{c}}$ of the regenerated cellulose sample in cuprammonium solutions with different $C_{\mathrm{OH}}$ were measured under the conditions of constant $C_{\mathrm{Cell}}, C_{\mathrm{Cu}}$, and $C_{\mathrm{NH}_{3}}$ $\left(0.068,0.052\right.$, and $2.4 \mathrm{moll}^{-1}$, respectively). The results are shown in Figure 3. Figure 3 clarifies that $S_{\mathrm{c}}$ is 0 in $C_{\mathrm{OH}}$ region less than $0.08 \mathrm{moll}^{-1}$ (that is, $C_{\mathrm{NaOH}}=c a .0 .004 \mathrm{moll}^{-1}$ ) and increases rather steeply with an increase in $C_{\mathrm{OH}}$ approaching a maximum value ( $c a$. $50 \%$ ) at $C_{\mathrm{OH}}=c a .0 .35 \mathrm{moll}^{-1}$ (that is, $C_{\mathrm{NaOH}}=$ ca. $0.16 \mathrm{moll}^{-1}$ ), then rapidly decreases to $S_{\mathrm{c}}=0$ in the $C_{\mathrm{OH}}$ region more than $0.6 \mathrm{moll}^{-1}$ (corresponding to $C_{\mathrm{NaOH}}=c a .0 .5 \mathrm{moll}^{-1}$ ). The $C_{\mathrm{OH}}$ value giving maximum $S_{\mathrm{c}}$ roughly corresponds to the $C_{\mathrm{OH}}$ value where cuprammonium complex in the solution goes into the

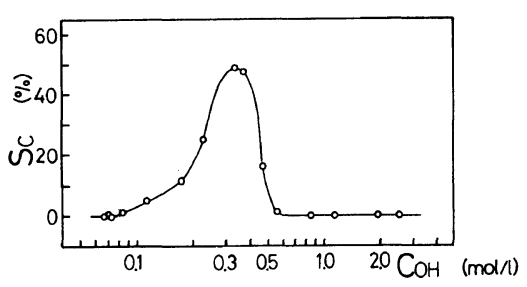

Figure 3. Solubility of the regenerated cellulose sample $\left(S_{\mathrm{c}}\right)$ in cuprammonium solution with different hydroxyl ion concentration $\left(C_{\mathrm{OH}}\right)$. 
undissociated state. The experimental fact that dissolving power of cuprammonium solution rapidly decreases in the region $C_{\mathrm{NaOH}}>0.5$ moll $1^{-1}$ quite well corresponds to the results given by Sobue ${ }^{5}$ and the $C_{\mathrm{NaOH}}$ value which gives the maximum value of $S_{\mathrm{c}}\left(C_{\mathrm{NaOH}}=0.16\right.$ moll $1^{-1}$ ) also well corresponds to the results given by Hess. ${ }^{4}$ The results also show that if we choose two $C_{\mathrm{OH}}$ regions $\left(C_{\mathrm{OH}}<0.08 \mathrm{moll}^{-1}\right.$ and $C_{\mathrm{OH}} \geqq 0.6 \mathrm{moll}^{-1}$ ) where no dissolution of cellulose takes place, the solid cellulose simply absorbs copper dissolved in the solution and this phenomenon might be approximately attributed to a kind of absorption equilibrium between $\mathrm{Cu}$, solid cellulose and solid $\mathrm{Cu}$ absorbing cellulose.

Figure 4 shows the plot of molar absorption of $\mathrm{Cu}$ absorbed on cellulose $M_{\mathrm{Cu}} / M_{\mathrm{Cell}} v s$. initial cellulose concentration $C_{\text {Cell }}\left(\mathrm{moll}^{-1}\right)$ charged in a cuprammonium solution with constant $C_{\mathrm{OH}}\left(\mathrm{a}, C_{\mathrm{OH}}=0.83 \mathrm{moll}^{-1} ; \mathrm{b}, C_{\mathrm{OH}}=\right.$ $0.18 \mathrm{moll}^{-1}$; c, $C_{\mathrm{OH}}=0.07 \mathrm{moll}^{-1}$ ). Absolute value of $M_{\mathrm{Cu}} / M_{\mathrm{Cell}}$ for the system with $C_{\mathrm{OH}}=$ $0.83 \mathrm{moll}^{-1}$ is far larger than that for the system with $C_{\mathrm{OH}}=0.07 \mathrm{moll}^{-1}$. For the system with $C_{\mathrm{OH}}=0.83 \mathrm{moll}^{-1}$ there are two regions: region $\mathrm{A}, C_{\mathrm{Cell}} \leqq 0.04 \mathrm{moll}^{-1}$ where $M_{\mathrm{Cu}} / M_{\text {Cell }}$ is constant $(=0.65)$; region $\mathrm{B}, C_{\mathrm{Cell}}>$ $0.04 \mathrm{moll}^{-1}$ where $M_{\mathrm{Cu}} / M_{\mathrm{Cell}}$ decreases monotonically with increase in $C_{\text {Cell }}$. Similar line

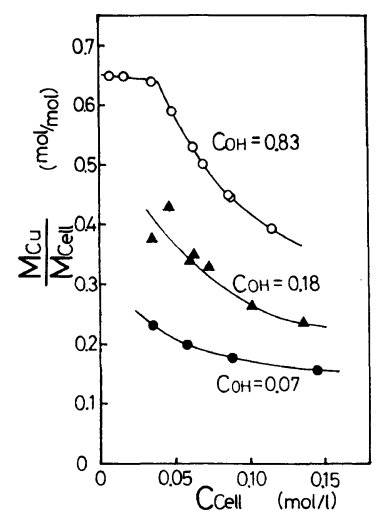

Figure 4. Plot of molar absorption of $\mathrm{Cu}$ absorbed by cellulose $\left(M_{\mathrm{Cu}} / M_{\text {Cell }}\right)$ vs. initial cellulose concentration $\left(C_{\mathrm{Cu}}\right)$ in cuprammonium solution: $\bigcirc ; C_{\mathrm{OH}}=0.83 \mathrm{moll}^{-1}$, $\Delta ; C_{\mathrm{OH}}=0.18 \mathrm{moll}^{-1} ; \bigcirc, C_{\mathrm{OH}}=0.07 \mathrm{moll}^{-1}$. as observed in the region $B$ was obtained at $C_{\text {Cell }}>0.035 \mathrm{moll}^{-1}$ for the system with $C_{\mathrm{OH}}=0.18 \mathrm{moll}^{-1}$ and $C_{\mathrm{OH}}=0.07 \mathrm{moll}^{-1}$. The appearance of region $A$ suggests that cellulose has its upper limit of absorption cite for cuprammonium complex. Constant $(=0.65)$ value of $M_{\mathrm{Cu}} / M_{\text {cell }}$ in the system where cuprammonium complex exists far larger than cellulose well coincides with our previous result shown for cellulose dissolved in cuprammonium solution, ${ }^{1}$ predicting that structure of the present $\mathrm{Cu}$-absorbing cellulose might have one to one correspondence to the structure of cellulose-cuprammonium complex in its solution.

In a separate experiment we confirmed that the cotton linter and soft wood pulp with different $D P_{\mathrm{v}}$ and morphology dispersed in the same system with $C_{\mathrm{OH}}=0.83 \mathrm{moll}^{-1}$ proved to show almost same upper limit value of $M_{\mathrm{Cu}} / M_{\text {Cell }}(=0.65)$ obtained here, suggesting that this absorption reaction has some simple stoichiometrical chemical reaction nature irrespective of the super-molecular structure of cellulose. The region $\mathrm{B}\left(C_{\mathrm{Cu}} / C_{\mathrm{Cell}} \leqq 1.4\right)$ is useful when we analyze an absorption equilibrium between cellulose and cuprammonium complex at constant $C_{\mathrm{OH}}$. Note that cuprammonium complex is dissociated in the system with $C_{\mathrm{OH}}=0.18 \mathrm{moll}^{-1}$ and $C_{\mathrm{OH}}=0.07 \mathrm{~mol}$ $1^{-1}$, and not dissociated in the system with $C_{\mathrm{OH}}=0.83 \mathrm{moll}^{-1}$.

Figure 5 shows the molar absorption of $\mathrm{Cu}$ on undissolved cellulose $\left(M_{\mathrm{Cu}} / M_{\mathrm{Cell}}\right)$ treated by

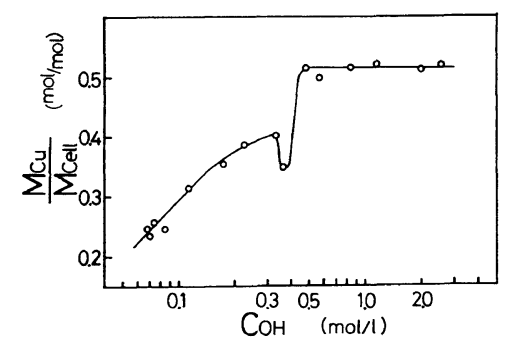

Figure 5. Relation between the molar absorption of $\mathrm{Cu}$ on undissolved cellulose $\left(M_{\mathrm{Cu}} / \boldsymbol{M}_{\mathrm{Cell}}\right)$ and hydroxyl ion content $\left(C_{\mathrm{OH}}\right)$ of the solution. 
above cuprammonium solutions under the constant $C_{\mathrm{Cu}} / C_{\mathrm{Cell}}(=c a$. 0.75$)$ as a function of $C_{\mathrm{OH}} \cdot M_{\mathrm{Cu}} / M_{\mathrm{Cell}}$ seems to increase almost linearly in $C_{\mathrm{OH}}$ region less than $0.6 \mathrm{moll}^{-1}$ with one exception at $C_{\mathrm{OH}}=0.38 \mathrm{moll}^{-1}$, attaining an asymptotic value $\left(M_{\mathrm{Cu}} / M_{\mathrm{Cell}}=0.52\right)$ in the region of $C_{\mathrm{OH}} \geqq 0.6 \mathrm{moll}^{-1}$.

According to Hess and his coworker ${ }^{4}$ who studied an equilibrium for the cellulose-cuprammonium solution system, the present case can be described by $\mathrm{Cu}$-absorbing equilibrium on cellulose solid in the solid-liquid coexisting system with cellulose and cuprammonium solutions as followed:

$$
\frac{[\mathrm{Cell} \cdot \mathrm{Cu}]}{[\mathrm{Cell}] \times[\mathrm{Cu}]}=K
$$

Here, symbols are defined as follows:

$[\mathrm{Cu} \cdot \mathrm{Cell}]$, concentration of $\mathrm{Cu}$-absorbing cellulose (that is, $1000 \times\left(w_{\mathrm{Cu}(\mathbf{a})} / 63.55\right) /(142.8 /$ $\rho)$ ); $[\mathrm{Cu}]$, concentration of $\mathrm{Cu}$ remained in cuprammonium solution (that is, $1000 \times$ $\left.\left(w_{\mathrm{Cu}(\mathrm{na})} / 63.55\right) /(142.8 / \rho)\right)$; [Cell], concentration of cellulose not absorbing $\mathrm{Cu}$ (that is, $C_{\text {cell }}-[\mathrm{Cu} \cdot \mathrm{Cell}]$ )

$[\mathrm{Cu} \cdot \mathrm{Cell}] /[\mathrm{Cu}][\mathrm{Cell}]$ is shown as a function of $C_{\mathrm{Cu}} / C_{\mathrm{Cell}}$ in Figure 6 using the data points obtained in Figure 4 (region $B$ in the system with $\left.C_{\mathrm{OH}}=0.83 \mathrm{moll}^{-1}\right) .[\mathrm{Cu} \cdot \mathrm{Cell}] /$ $[\mathrm{Cu}] \times[\mathrm{Cell}]$ has almost constant value irrespective of $C_{\mathrm{Cu}} / C_{\mathrm{Cell}}$ in every three $C_{\mathrm{OH}}$ concentration $\left(C_{\mathrm{OH}}=0.83,0.18\right.$, and $0.07 \mathrm{~mol}$ $\left.1^{-1}\right)$. Here, we assumed as a zero-th order

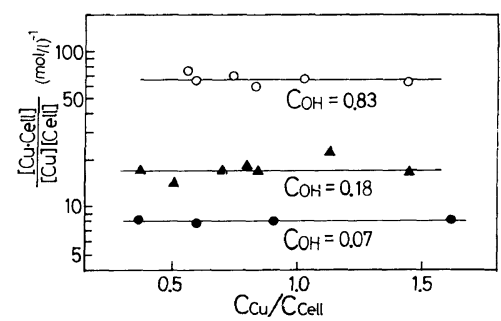

Figure 6. A plot of $\log [\mathrm{Cu} \cdot \mathrm{Cell}] /[\mathrm{Cu}] \times[\mathrm{Cell}]$ vs. $C_{\mathrm{Cu}} / C_{\mathrm{Cell}}$ in the cuprammonium-cellulose system: $\bigcirc$, $C_{\mathrm{OH}}=0.83 \mathrm{moll}^{-1} ; \boldsymbol{\Delta}, C_{\mathrm{OH}}=0.18 \mathrm{moll}^{-1} ; \boldsymbol{O}, C_{\mathrm{OH}}=0.07$ $\mathrm{moll}^{-1}$. approximation in the case of systems with $C_{\mathrm{OH}}=0.18 \mathrm{moll}^{-1}$ where a part of cellulose dissolves, that the dissolved cellulose absorbs cuprammonium complex in the same molar ratio as determined for undissolved cellulose. The basic equilibrium of cellulose-cuprammonium complex formation reaction between one mol of cellulose and one mol of cuprammonium complex can be expected also in the solid-liquid coexisting system as followed:

$$
[\mathrm{Cu}]+[\mathrm{Cell}] \leftarrow \rightarrow[\mathrm{Cu} \cdot \text { Cell }]
$$

Using the above results and the data points obtained under constant $C_{\mathrm{Cu}} / C_{\text {Cell }}(=0.75)$ in Figure 5 the similar analysis was carried out to clarify the influence of $\mathrm{OH}^{-}$on the absorption equilibrium. Following equilibrium and relationship might be expected for the present case:

$$
\begin{gathered}
{[\mathrm{Cu}]+[\mathrm{Cell}]+\mathrm{Y}\left[\mathrm{OH}^{-}\right] \leftarrow[\mathrm{Cu} \cdot \mathrm{Cell}]} \\
\frac{[\mathrm{Cell} \cdot \mathrm{Cu}]}{[\mathrm{Cell}] \times[\mathrm{Cu}] \times\left[\mathrm{OH}^{-}\right]^{Y}}=K \\
\log \frac{[\mathrm{Cell} \cdot \mathrm{Cu}]}{[\mathrm{Cell}] \times[\mathrm{Cu}]}=\log K^{\prime \prime}+Y \log \left[\mathrm{OH}^{-}\right]
\end{gathered}
$$

Here, symbols are defined as follows:

$\left[\mathrm{OH}^{-}\right]$, concentration of $\mathrm{OH}^{-}$ion (We use the initial $C_{\mathrm{OH}}$ in the cuprammonium solution because the change of $C_{\mathrm{OH}}$ by the complex formation reaction is small.); $Y$, reaction order of $\mathrm{OH}^{-}$

The results are shown in Figure 7. Here, we assumed as a zero-th order approximation that, in the $C_{\mathrm{OH}}$ region where a part of cellulose dissolves, the dissolved cellulose absorb cuprammonium complex in the same molar ratio as determined for undissolved cellulose. Thus, the accuracy for this analysis is expected to be low in the $C_{\mathrm{OH}}$ region around $0.35 \mathrm{moll}^{-1}$ where cellulose shows higher solubility in cuprammonium solution. Figure 7 shows that reaction order of $\mathrm{OH}^{-}(Y)$ is almost 1.0 in the region of $C_{\mathrm{OH}}<0.3 \mathrm{moll}^{-1}$ but $Y$ is ca. 0 in the 


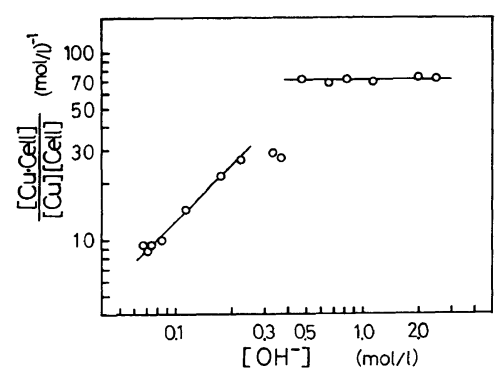

Figure 7. A plot of $\log [\mathrm{Cu} \cdot \mathrm{Cell}] /[\mathrm{Cu}] \times[\mathrm{Cell}] v s$. $\log \left[\mathrm{OH}^{-}\right]$in the cuprammonium-cellulose system which shows the reaction order of the hydroxyl ion.

region of $C_{\mathrm{OH}}>0.5 \mathrm{moll}^{-1}$. This suggests that when cuprammonium complex is dissociated into $\mathrm{OH}^{-}$ion and cation, the $\mathrm{OH}^{-}$ion contributes to the $\mathrm{Cu}$-absorption reaction equilibrium, but when cuprammonium complex is expected not to be dissociated, the $\mathrm{OH}^{-}$ion has no contribution to the $\mathrm{Cu}$-absorption reaction despite large amount of $\mathrm{OH}^{-}$ion existing in the system. The whole absorption schemes are shown in the following equations:

$$
\begin{gathered}
\text { Cell }-\mathrm{OH}+{\text { (cuprammonium complex })^{+}}^{+} \mathrm{OH}^{-} \leftarrow \rightarrow \mathrm{Cu}^{+} \cdot \mathrm{Cell}^{-}+\mathrm{H}_{2} \mathrm{O} \\
\left(C_{\mathrm{OH}}<0.3 \mathrm{moll}^{-1}\right)
\end{gathered}
$$

$$
\begin{aligned}
\text { Cell }-\mathrm{OH}+\text { cuprammonium complex } \\
\leftarrow \rightarrow \mathrm{Cu} \cdot \text { Cell } \\
\left(C_{\mathrm{OH}}>0.5 \mathrm{moll}^{-1}\right)
\end{aligned}
$$

The study of Reeves ${ }^{2}$ was carried out under the condition of $C_{\mathrm{OH}}<0.3 \mathrm{moll}^{-1}$ in the initial cuprammonium solution and he proposed the diol anion structure of the cellulose-cuprammonium complex, which coincides with scheme (14) in this study. Scheme (14) also explains the findings by Hess ${ }^{4}$ that an addition of $\mathrm{NaOH}$ resulted in an increases in optical rotary power of the cellulose-cuprammonium solution system, because the addition of $\mathrm{OH}^{-}$ion into the system promotes the cellulose-cuprammonium complex forming reaction and the $\mathrm{Cu}-\mathrm{ab}$ sorbing reaction equilibrium in the region of $C_{\mathrm{OH}}>0.5 \mathrm{moll}^{-1}$ are firstly reported in this study.

Considering our previous study, ${ }^{1}$ the formation of cellulose-cuprammonium complex, if any, in the present system may be tentatively illustrated as follows;
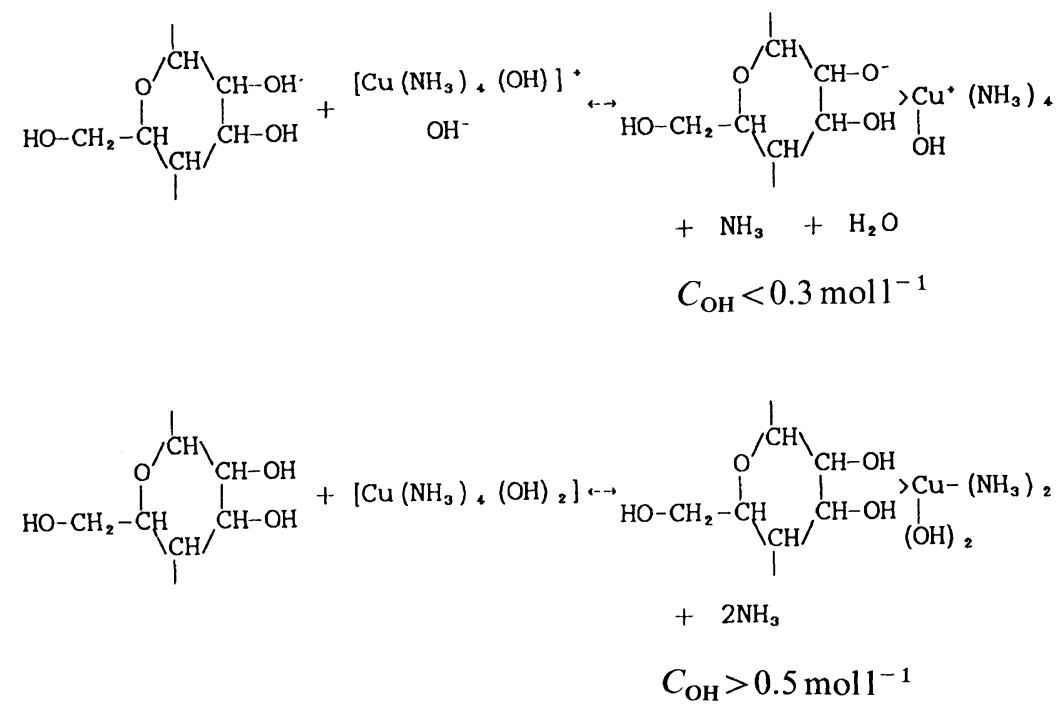
In this connection, sodium cation $\left(\mathrm{Na}^{+}\right)$ might not contribute in the above process because similar analysis using $\mathrm{Na}^{+}$concentration $\left(\left[\mathrm{Na}^{+}\right]\right)$instead of $\left[\mathrm{OH}^{-}\right]$term in Figure 7 did not give any linear line.

The absorption equilibrium proposed here together with our previous study ${ }^{1}$ also suggests that as the dissolved state of cellulose in cuprammonium solution all glucopyranose units constituting cellulose do not always coordinate cuprammonium complex. This means that when about a half of glucopyranose units are substituted as a diol anion salt of the cuprammonium complex, this cellulose derivative is soluble in the aq cuprammonium solution or water, and about a half of cuprammonium complex exists away from cellulose molecular in the cellulose-cuprammonium solution. If we can make the cellulose derivative described above or at least copper-coordinated cellulose derivative in a separate process, they might be soluble in aq ammonia or water. This principle might lead us to a new way producing the cellulose-cuprammonium solution which has low concentration of copper and ammonia. In fact, we succeeded in preparing the above solution as described in Experimental section: First, a DBC sample with $C_{\mathrm{Cu}} / C_{\text {cell }}$ value $(=c a$. 0.52 ) was prepared by treating cellulose with cuprammonium solution which has no cellulose dissolving power $\left(C_{\mathrm{OH}} \geqq 0.5 \mathrm{moll}^{-1}\right)$. The DBC contains copper and $\mathrm{NaOH}$ (or $\mathrm{OH}^{-}$) but lose ammonia by drying process. The DBC sample was proved to give clear solution by mixing with aq $2 \mathrm{wt} \%$ ammonia solution at polymer concentration level of $c a .5 \mathrm{wt} \%$. By this method we can produce the cellulose-cuprammonium solution which contains $1 / 2$ copper and $1 / 3$ ammonia in thier amounts, compared with those employed in conventional cellulose-cuprammonium solution.

\section{CONCLUSION}

An attempt was made to clarify chemical reaction nature of cellulose when dissolved in a cuprammonium solution in more detail. For this purpose an absorption experiment of cuprammonium complex in the solid-liquid coexisting system was carried out by either varying initial molar ratio of solid cellulose to cupric ion or varying hydroxyl ion strength in aq cuprammonium complex. Analysis in view of absorption equilibrium revealed that the following absorption equilibria held depending on $\mathrm{OH}$ ion strength $\left(C_{\mathrm{OH}} ; \mathrm{moll}^{-1}\right)$ in the system:

$$
\begin{gathered}
\text { Cell }-\mathrm{OH}+(\mathrm{CA} \text { complex })^{+} \\
+\mathrm{OH}^{-} \leftarrow \rightarrow \mathrm{Cu}^{+} \cdot \mathrm{Cell}^{-}+\mathrm{H}_{2} \mathrm{O} \\
C_{\mathrm{OH}}<0.3 \mathrm{moll}^{-1} \\
\mathrm{Cell}-\mathrm{OH}+\mathrm{CA} \text { complex } \leftarrow \rightarrow \mathrm{Cu} \cdot \text { Cell } \\
C_{\mathrm{OH}}>0.5 \mathrm{moll}^{-1}
\end{gathered}
$$

The above schemes were found to reasonably explain the results obtained past. It was also confirmed that saturated absorbing copper is at most $0.65 \mathrm{~mol}$ per glucopyranose unit, which well coincides with the value evaluated for the cellulose-cuprammonium system in our previous study. Using this above results as tentative new cellulose dissolving process is proposed, in which the less amount of copper and $\mathrm{NH}_{3}$ are employed, compared with those used for conventional process.

\section{REFERENCES}

1. I. Miyamoto, M. Inamoto, T. Matsui, M. Saito, and K. Okajima, Polym. J., 27, 1113 (1995).

2. R. E. Reeves, Science, 99, 148 (1944).

3. K. Hess and E. Messmer, Ber., 54, 834 (1921), ibid., 55, 2432 (1922), Ann. Chem., 435, 1 (1923).

4. K. Hess and C. Trogus, Z. Phys. Chem., A, 145, 401 (1929).

5. H. Sobue, Jinzosenigaku, 120 (1950).

6. W. Traube, Ber., 54, 3320 (1920).

7. S. M. Neale, J. Textile Inst., 16, T363 (1925).

8. Th. Liser and R. Ebert, Ann. Chem., 528, 276 (1937); ibid., 534, 94 (1937).

9. K. H. Meyer, Hochpolymer Chemie, II, 274 (1940).

10. W. Brown and R. Wikström, Eur. Polym. J., 1, 1 (1966).

11. The Chemical Society of Japan, Ed., "Kagaku Binran Kisohen,” Vol. II, Maruzen Co., Tokyo, 1984, p 338. 